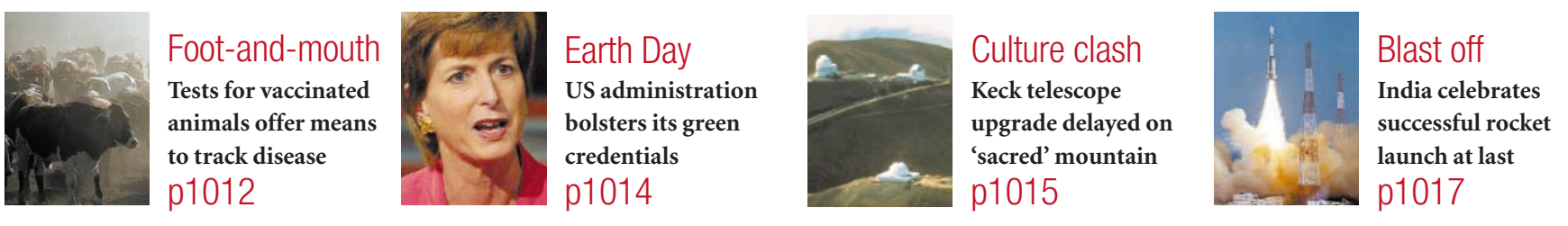

\title{
Russia needs help to fend off potato famine, researchers warn
}

\section{Quirin Schiermeier, Munich}

Aggressive strains of potato blight could trigger a potentially catastrophic potato famine in Russia, scientists have warned.

The researchers want an international effort to provide Russian potato-growers with fungicides and seed varieties that are resistant to virulent late blight pathogens, which last year destroyed more than $15 \%$ of the country's total crop.

"The situation is worrying, and it could quickly worsen," warns Kandukuri Raman, a plant scientist at Cornell University in Ithaca, New York, and head of the CornellEastern Europe-Mexico (CEEM) project on control of potato late blight .

Potato late blight, which is caused by the fungus Phytopthora infestans and originated in Mexico, is one of the world's most devastating crop diseases, with annual losses and fungicide costs estimated at US $\$ 3$ billion.

Potatoes are a vital subsistence crop grown by poor Russians who cannot afford to buy vegetables or meat. Russia is the world's second-largest potato producer, after China.

Raman fears that the state of its economy means that Russia will not be able to control the disease without outside support. He points out that Russia has no strong potatobreeding programme aimed at developing varieties resistant to late blight.

Spores of $P$. infestans constantly reproduce and take on characteristics that enable them to survive and spread. The new, aggressive strains proliferate freely and can survive in the soil over winter, attacking potatoes in summer and destroying the harvest.

Late blight caused the Irish potato famine in the 1840s, leading to the death of a million people and a huge wave of migration. But fungicides have been available since the late nineteenth century, and have fought off even the more virulent strains across Europe. However, late blight remains a major threat to small farmers and householders in Russia, who lack access to suitable fungicides.

"Pesticide-resistant and virulent strains of $P$. infestans have appeared in the major

\section{Smithsonian closure plan under fire}

\section{Josette Chen}

Leading Republicans have attacked plans by the Smithsonian Institution to close its Conservation Research Center (CRC) at Front Royal, Virginia (see Nature 410, 727; 2001).

Congressman Frank Wolf (Republican, Virginia), a member of the House Appropriations Committee which controls the government's share of the Smithsonian budget, said: "I am extremely disappointed and angry with the Smithsonian. This decision - and the way it has been announced - is shortsighted and ill-advised."

Senator John Warner (Republican,

Virginia), who visited the facility on 21 April, said the closure "does not reflect a consensus of views in the research community".

In a letter to the Smithsonian's secretary Larry Small, Sherwood Boehlert (Republican, New York), chairman of the House Science Committee, said: "To close the CRC or curb its capabilities would be a blow to the Smithsonian and its reputation, as well as to the nation and the world."

The closure will be considered on 7 May by the Smithsonian's governing board. It must then be approved by Congress, where influential members favour the centre's continued operation.

At a meeting with 500 museum staff on 17 April, Small discussed the Smithsonian's need to refurbish buildings as part of a proposed reorganization. But he did not detail any cuts in research programmes.

The Smithsonian has rejected plans from the Fish and Wildlife Service for joint management of the centre. But last week National Zoo director Lucy Spelman seemed to retract her earlier firm announcement of its closure. Chris Wemmer, the centre's associate director, says she referred to it as only a proposal.

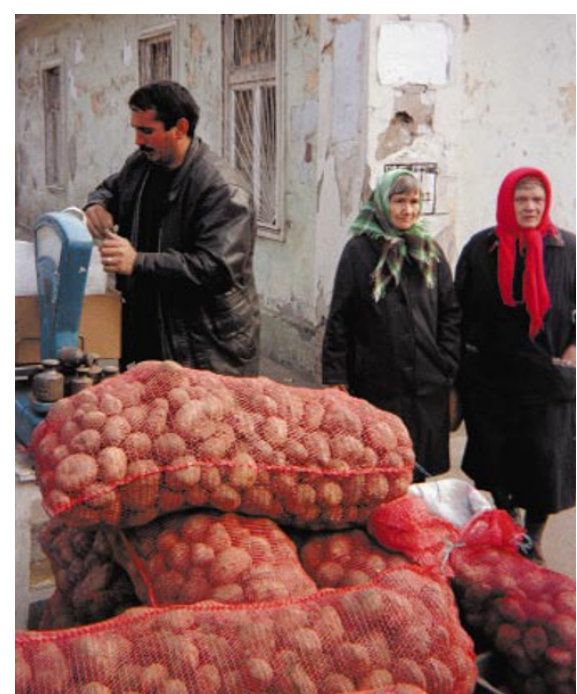

At risk: Russia's potatoes are vulnerable because their growers lack access to fungicides.

potato-growing regions in Russia," says Patrick Russo, a plant geneticist at the University of Helsinki in Finland and a technical adviser on control of late blight in Russia. Even types of potato that showed some resistance to late blight "are no longer resistant to the newer strains", he adds.

The CEEM project aims to help distribute seeds of resistant potato varieties to Russian smallholders, but has limited resources. It is also collaborating with Polish and Russian scientists to test wild potato species, and to study the molecular biology of the interaction between $P$. infestans and the potato.

Much of the work is being done at the N. I. Vavilov All-Russian Scientific Research Institute of Plant Industry in St Petersburg, which holds one the world's oldest and largest potato collections.

The US Department of Agriculture and the CEEM project are sponsoring a June workshop in Warsaw on potato late blight. Experts from ten countries will discuss the use of plant genetics and traditional breeding methods to develop broad-based resistance, and explore the possibility of a programme to forecast the arrival of different strains of the pathogen.

http://www.cals.cornell.edu/dept/plantbreed/CEEM 